\title{
Cuticles of Karinopteris beneckei (Potonié ex Huth) Boersma emend., a mariopterid seed fern from the Upper Carboniferous of Lower Silesia (Poland)
}

\author{
Michael Krings ${ }^{1}$ \& Stephan Schultka ${ }^{2}$
}

With 1 figure and 4 plates

\begin{abstract}
Cuticles of Karinopteris beneckei are described from the upper Westphalian A of Lower Silesia (Poland). The diagnosis for Karinopteris beneckei (Potonié ex Huth, 1912) Boersma, 1972 is emended based on additional macroscopic observations and data on the epidermal anatomy. Karinopteris beneckei closely resembles $K$. acuta with regard to macromorphology, but a number of features indicate that the two taxa are not conspecific. Some comments are offered on the paleobiological and paleoecological implications of particular features observed from $K$. beneckei (e.g., climber hooks confined to distal frond portions, large emergences, and minute stomata) where they are considered relative to adaptations of the plant to special mechanical, ecological, and physiological requirements.
\end{abstract}

Key words: Climber hook, Cuticular analysis, Karinopteris beneckei, Mariopteris, Schatzlarer Schichten, Stoma, Emergence, Westphalian.

\section{Zusammenfassung}

Aus dem oberen Westfal A von Niederschlesien (Polen) werden erstmalig die Kutikulen von Karinopteris beneckei beschrieben. Auf der Basis zusätzlicher Beobachtungen zur Makromorphologie und unter Einbeziehung der epidermalen Anatomie wird die Diagnose für Karinopteris beneckei (Potonié ex Huth, 1912) Boersma, 1972 emendiert. Karinopteris beneckei und K. acuta sind makromorphologisch sehr ähnlich; einige Unterschiede unterstützen allerdings die taxonomische Eigenständigkeit beider Formen. Einige Merkmale von $K$. beneckei (z.B. das ausschließliche Vorkommen von Kletterhaken im distalen Teil der Wedel, ein besonderer Typ von Emergenzen, bemerkenswert kleine Stomata) werden in Hinsicht auf ihre Signifikanz in Paläobiologie und -ökologie diskutiert; vermutlich stellen sie Adaptationen der Pflanze an bestimmte Habitatkonditionen dar.

Schlïsselwörter: Karinopteris beneckei, Kletterhaken, Kutikularanalyse, Mariopteris, Schatzlarer Schichten, Spaltöffnung, Emergenz, Westfal.

\section{Introduction}

The Late Carboniferous mariopterid seed ferns (pteridosperms) are represented by several genera, including Mariopteris, Karinopteris, and Pseudomariopteris. They generally were small to medium-sized vine- or liana-like plants, with stems that rarely exceeded $2 \mathrm{~cm}$ in diameter, and bipartite (in Karinopteris and Pseudomariopteris) or quadripartite (in Mariopteris), up to 40 or $45 \mathrm{~cm}$ long fronds. An enlarged, basal basiscopic lobe in the acroscopic and basiscopic pinnules positioned in the proximal portion of fully differentiated pinnae is consistently present in all taxa. Many mariopterids developed specialized hooks, usually from terminal extensions of pinna axes, which were effective as climbing aids (DanzéCorsin 1953, Boersma 1972, DiMichele et al. 1984, Kerp \& Barthel 1993, Steur 1995, Kerp \& Krings 1998, Krings \& Kerp 2000). In some species, the stems may also have had some capacity for attachment (Krings et al. 2001a). Moreover, shoot-borne roots, catching and ratcheting between the support plants' branching systems and

\footnotetext{
1 Department of Ecology and Evolutionary Biology, and Natural History Museum and Biodiversity Research Center, The University of Kansas, Lawrence KS 66045-7534, U.S.A., and Forschungsstelle für Paläobotanik am Geologisch Paläontologischen Institut und Museum, Westfälische Wilhelms-Universität Münster, Hindenburgplatz 57, 48143 Münster, Germany. (Author for correspondence and reprint requests)

${ }^{2}$ Naturhistorisches Forschungsinstitut - Museum für Naturkunde, Institut für Paläontologie, Invalidenstrasse 43, 10115 Berlin, Germany.

Received March 2002, accepted June 2002
} 
foliage, may have created an additional interaction that provided mechanical stability (Krings pers. obser.).

Mariopterids were among the earliest Carboniferous seed ferns studied by means of cuticular analysis (Huth 1912b, 1913a, b, Potonié 1913, Gothan 1915, Walton 1923, Kidston 1925, Lutz 1938). Subsequent research has substantially expanded our knowledge of the epidermal anatomy of these ancient plants (e.g., Barthel 1962, DiMichele et al. 1984, Kerp \& Barthel 1993, Krings \& Kerp 2000, Krings et al. 2001b). It has been established that mariopterid cuticles provide a wealth of features significant in taxonomy, but also useful with regard to paleobiological and paleoecological considerations. Although cuticular analysis has long since proven to serve a more complete understanding of mariopterid pteridosperms based on biological criteria, the epidermal anatomy of most taxa has been disregarded to date. Thus, our perception of their natural relationships continues to be incomplete, and paleobiology and paleoecology remain largely unknown.

Karinopteris beneckei (Potonié ex Huth) Boersma is an intriguing taxon of mariopterid foliage, which is locally abundant in the Westphalian $\mathrm{A} / \mathrm{B}$ of Lower Silesia (Poland), while it is rare or absent elsewhere, and yet, little attention has been directed at its systematic position, paleobiology, and paleoecology. In this paper, we provide the first descriptions of the epidermal anatomy of $K$. beneckei based on cuticles from the upper Westphalian A of Lower Silesia. Karinopteris beneckei is compared with other mariopterids, and comments are offered on the paleobiological and paleoecological significance of specific macromorphological and epidermal features.

\section{Karinopteris beneckei (Potonié ex Huth) Boersma}

The taxon was first recognized by Potonié, and the name Mariopteris beneckei suggested in a manuscript. However, since this manuscript was never published, the taxon remained invalid until it was formally described by Huth in 1912a (p. 74-82). This author provided a specific diagnosis, description, and illustrations; however, a holotype was not designated. The circumscription of $M$. beneckei was later refined by DanzéCorsin (1953: 100-106), who also designated a lectotype (i.e., the specimen originally illustrated by Huth in 1912a: fig. 34). Eventually, Boersma (1972: 76) transferred M. beneckei to Karinopteris, a genus introduced to accomodate those taxa formerly included in Mariopteris that possess bipartite fronds.

Based on the references compiled in Jongmans \& Dijkstra $(1960,1968)$ and Dijkstra \& van Amerom (1983), Karinopteris beneckei appears to have had a long stratigraphic range and rather wide geographical distribution, having been reported from Namurian $\mathrm{A}$ to Westphalian $\mathrm{C}$ localities throughout central and eastern Europe. However, most of the accounts are questionable. The taxon is morphologically highly variable and usually a rare element in the fossil record. Thus, the identification of smaller specimens is not reliable. The earliest occurrence of $K$. beneckei has been reported from the uppermost Namurian A of the Poreba Beds in Upper Silesia (Poland) (Migier 1972: pl. 11, fig. 6, 1973: pl. 4, fig. 5), but the material is fragmentary and assignment to any particular species is impossible. Stopa (1957: $55-57$ and pl. XIII, figs $2-5$, pl. XIV, figs $1-5$, pl. XV, figs 1-4) identifies fossils from the Namurian B of Zabrze, Upper Silesia (Poland), as $M$. beneckei based on resemblances with two specimens illustrated by Huth (1912a: figs 36, 37). However, according to Remy \& Remy (1959: 144/145), Huth's figure 37 (refigured here in pl. II, fig. 7) is Mariopteris hirsuta. The second specimen (fig. 36) belongs to $K$. beneckei, but displays tapering pinnule lobes, a feature not normally seen in this taxon. Because the specimens from Zabrze possess similar, tapering pinnule lobes, they were assigned to $K$. beneckei (Stopa 1957). A re-examination of Huth's specimen revealed that the tapering pinnule lobes represent a preservational artefact; originally, the lobes were rounded. We hold the opinion that Stopa's material from Zabrze consists of several taxa, including Karinopteris acuta and Mariopteris daviesoides. According to Jongmans \& Dijkstra (1960), K. beneckei was most widespread in the Westphalian $\mathrm{A} / \mathrm{B}$, having been recorded from localities in France (Danzé-Corsin 1953), Germany (Huth 1912a), Great Britain (e.g., Kidston 1925), Poland (Huth 1912a, 1913a), Russia (e.g., Zalessky \& Ėirkova 1938; Novik 1952), The Netherlands (Jongmans \& Gothan 1915; Jongmans 1953), and Turkey (Jongmans 1956). However, unequivocal $K$. beneckei fossils only come from the type area (i.e., the Westphalian-A-Btransition in the Schatzlarer Schichten of Lower Silesia) in Poland (cf. Huth 1912a) and the coal basins of northern France (cf. Danzé-Corsin 
1953). The other reports have to be regarded as questionable. For example, the specimens from Great Britain figured by Kidston (1925: pl. CLII, figs $4,4 \mathrm{a}, 5,5 \mathrm{a})$ were re-identified as $M$. acuta $\mathrm{f}$. grandis and Diplotmema pilosum, respectively, by Danzé-Corsin (1953: 105). The accounts from Germany (Huth 1912a) and the Netherlands (Jongmans \& Gothan 1915; Jongmans 1953) are based on a few small fragments, which do not permit reliable identification. Zalessky \& Čirkova (1938: figs 30, 31) and Novik (1952: pl. 50, fig. 1), among others, figure specimens from the Donetz Basin (Russia). However, the illustrations are poor and do not permit confirmation of the identification. Karinopteris beneckei from strata above the Westphalian $\mathrm{A} / \mathrm{B}$ has been reported from the coal basin of Azdavay (Westphalian B and C) in northern Anatolia (Turkey) (Jongmans 1956), but no material was illustrated.

\section{Material and methods}

The material for cuticular analysis comes from the upper Westphalian A of Lower Silesia (Poland), and was collected at Hausdorf (today Jugowice), a village near Neurode (today Nowa Ruda), Hangendzug, Schatzlarer Schichten. Specimens are stored in the collections of the Naturhistorisches Forschungsinstitut - Museum für Naturkunde, Zentralinstitut der Humboldt-Universität zu Berlin, Germany (collection number MB.Pb.2001/1459). Cuticles were prepared according to procedures outlined in Kerp \& Krings (1999). Pieces of rock containing plant remains were bulk-macerated in $45 \%$ hydrofluoric acid (HF) for one to three days. Plant remains were picked from the acid, gently washed in several rinses of distilled water, and subsequently macerated according to a modified procedure using Schulze's reagent $\left(\mathrm{HNO}_{3}\right.$ with a few crystals of $\mathrm{KClO}_{3}$ ). Macerated cuticles were washed, dehydrated in glycerine, and subsequently mounted in permanent glycerine-jelly microscope slides. Permanent slides are housed in the Berlin collection (collection numbers $\mathrm{MB} . \mathrm{Pb}$ 2002/995-MB.Pb 2002/1019). Additional microscope slides (slide numbers preceded by "Epid.Pr.") with cuticles of $K$. beneckei from Lower Silesia were provided by Prof. M. Barthel (Berlin, Germany). Hand specimens were photographed on low-speed panchromatic film (Ilford Pan E Plus) under cross-polarized light; cuticles were photographed on low-speed pan or orthochromatic film (Agfapan 25 ISO, Macophot Ort 25 ISO).

\section{Systematics}

Genus Karinopteris Boersma, 1972

Species Karinopteris beneckei (Potonié ex Huth)

Boersma, emend. Krings et Schultka
Fig. 1, Plates 1-4

Selected references:

Mariopteris beneckei, Potonié, MSS.

1912a Mariopteris Beneckei, Huth, Gattung Mariopteris, p. 74-82, figs 34, 35, 38-40.

1913a Mariopteris cf. beneckei, Huth, Mariopteris Zeiller, in Gothan, Oberschlesische Steinkohlenflora, p. 101-102, pl. 21, fig. 1.

1913c Mariopteris Beneckei, Huth, Carbongattung Mariopteris, p. 382, no illustr.

1953 Mariopteris beneckei, Danzé-Corsin, Mariopteris, p. 100-106, pl. XIV, XV.

1972 Karinopteris beneckei, Boersma, Heterogeneity, p. 76, no illustr.

1973 Karinopteris beneckei, Boersma, Genus Mariopteris, p. 149, pl. II, fig. 2.

\section{Lectotype:}

Huth (1912a) figured several specimens, but did not specifically designate a holotype. Danzé-Cor$\sin$ (1953) selected Huth's fig. 34 as the lectotype. This specimen comes from the Westphalian A of Lower Silesia (Poland) and is today housed in the paleontological collections (Lithothèque) of the École et Observatoire des Sciences de la Terre, Institut de Géologie, Université Louis Pasteur, Strasbourg (France).

Emended specific diagnosis:

Fronds bipartite, up to $45 \mathrm{~cm}$ long, rather lax in appearance; blade bi- to tripinnate. Stipe and rachides longitudinally striated; cortical transverse sclerotic plates usually visible in stipe, but weakly developed, irregularly distributed; epidermal cells of stipe and rachides elongate, regularly arranged; stomata small, with dorsal and circumporal thickenings; two types of outgrowths occur, including large, multiseriate and multicellular, presumably glandular emergences ${ }^{3}$. Pinna axes of the penultimate order smooth or longitudinally striated, pubescent on adaxial and abaxial side; cortical transverse sclerotic plates not recognizable; epidermal cells of abaxial axis surface elongate, usually ending acutely; at least two types of outgrowths occur, including large emergences; penultimate order axes terminating in undifferentiated pinnules or in climber hooks. Pinna axes of the ultimate order smooth, pubescent, presence of emergences restricted to abaxial side; axes terminate in small pinnules or climber hooks. Lateral pinnules variously arranged,

\footnotetext{
3 These structures are here termed "emergences" although we recognize that it is equivocal as to wether they represent true emergences or trichomes, because their development either from epidermal and subepidermal tissues (i.e., emergence) or from epidermal tissue only (i.e., trichome) cannot be reconstructed.
} 

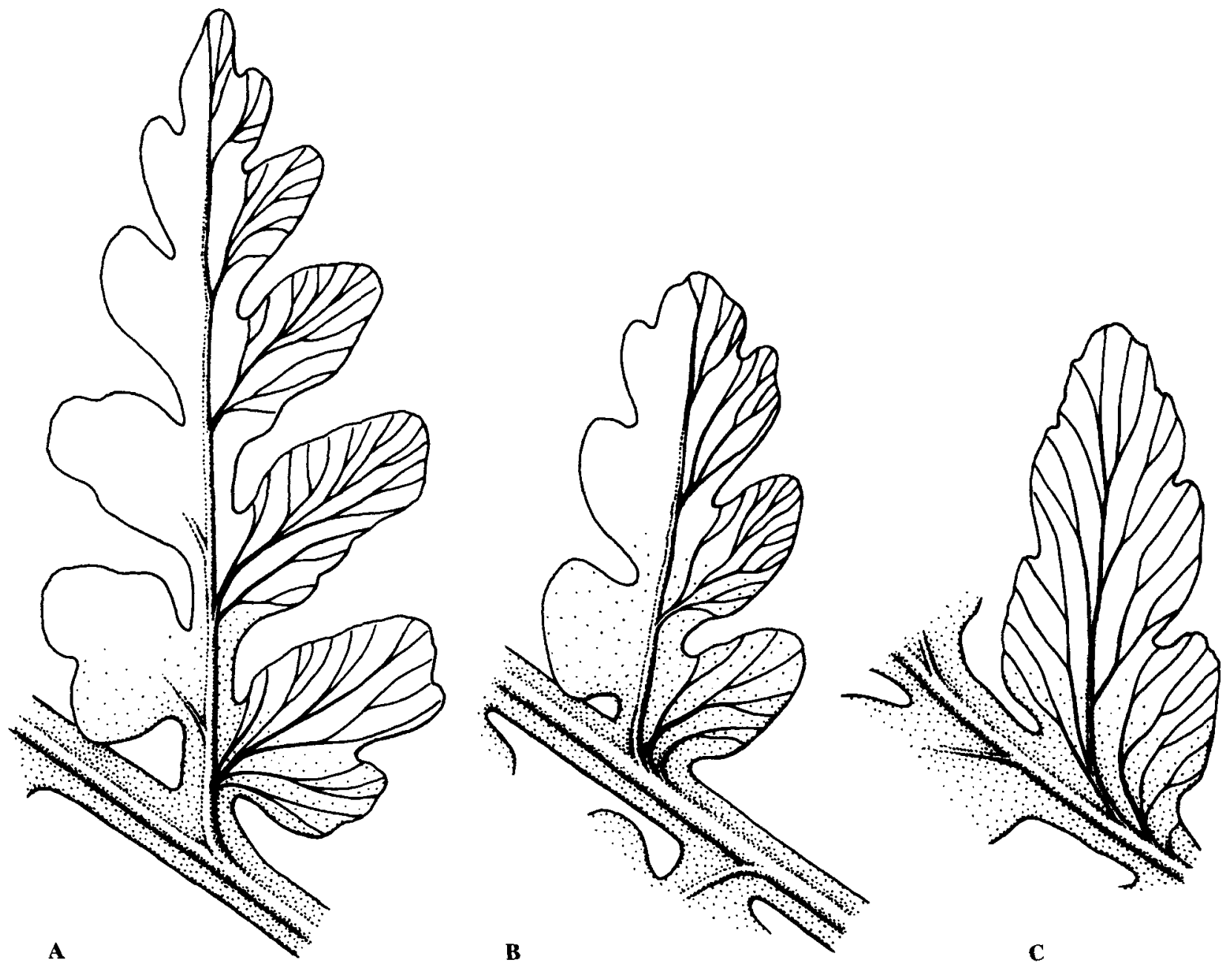

Fig. 1. Variability in pinnule morphology in fully differentiated pinnae of the ultimate order of Karinopteris beneckei. A. Profoundly lobed, slightly asymmetrical pinnule from the basal portion of a pinna; B. Lobed pinnule from the middle portion of a pinna; C. Distally positioned, slightly lobed pinnule.

loosely to densely; pinnules variable in size and shape, oblong (tongue-shaped) in general outline, entire-margined to profoundly lobed, with rounded or somewhat tapered apices, usually broadly attached, decurrent and acroscopically constricted; basal pinnules in fully differentiated pinnae attached by a pedicel; pinnules interconnected by narrow laminar rims on each side along the axis; basal lobes present in basal pinnules on acroscopic and basiscopic side of pinnae, but never prominent. Pinnae of the ultimate order in distal parts of pinnae of the penultimate order and in the entire uppermost portion of the blade less differentiated, individual parts fused, forming large, compound, and lobed pinnules, constricted at the base and attached by a broad pedicel. Venation strong but relatively loose; in compound pinnules, midvein prominent, sunken, decurrent, and somewhat undulated; lateral veins at acute angles, often faint in compressions, thinner than midvein, one to four times divided in their course to the magin. Pinnules hypostomatic. Costal and intercostal fields of adaxial pinnule surface hardly differentiated. Adaxial and abaxial pinnule surfaces pubescent; in compound pinnules, emergences present abaxially in the midvein area. Stomata small, occuring in intercostal fields; guard cells with tapering polar

Plate 1. Karinopteris beneckei from Lower Silesia (Poland). Paratype; most complete specimen, originally figured in Huth (1912a: fig. 38). Fuchsgrube bei Weisstein, Lower Silesia, Hangendzug, Schatzlarer Schichten (Westphalian A). MB.Pb.1980/ 504 ; scale bar $=1.0 \mathrm{~cm}$. 
F.

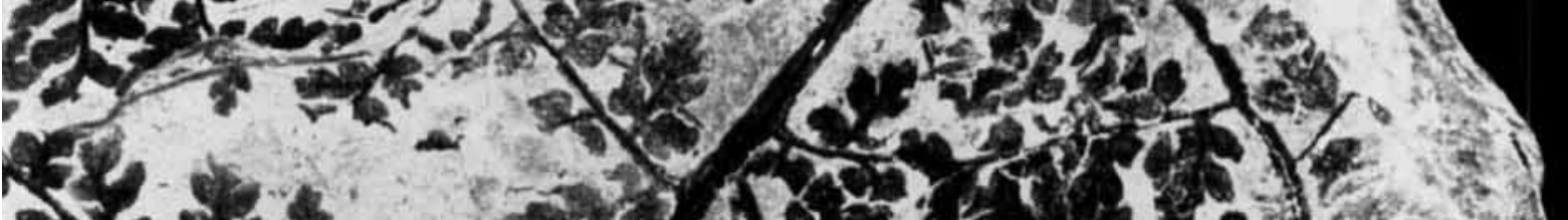

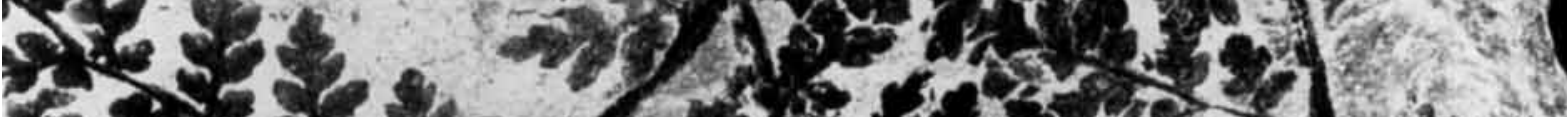

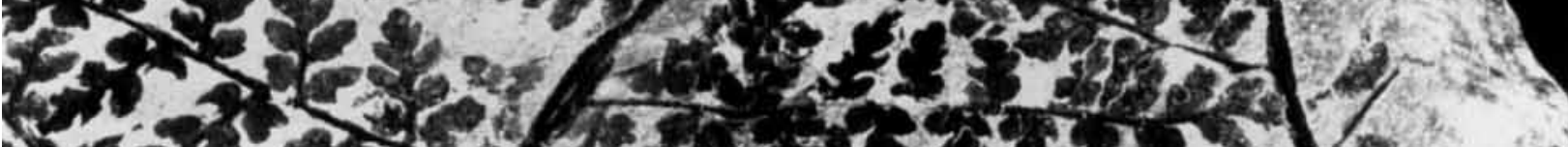

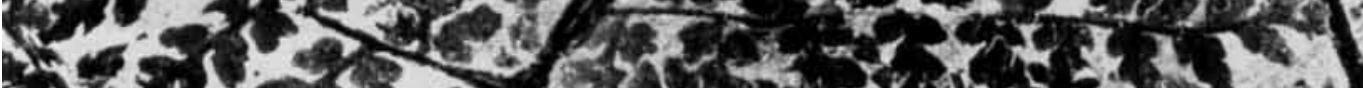
C.

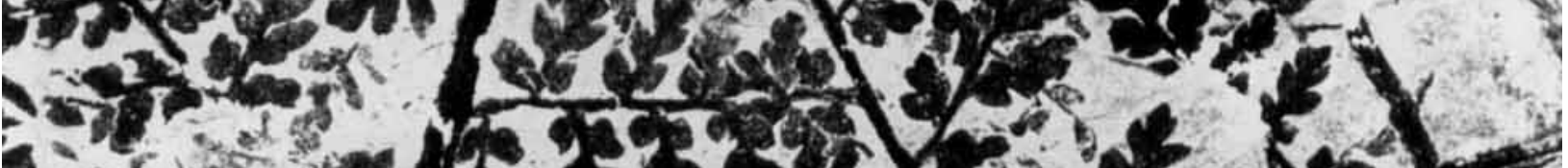

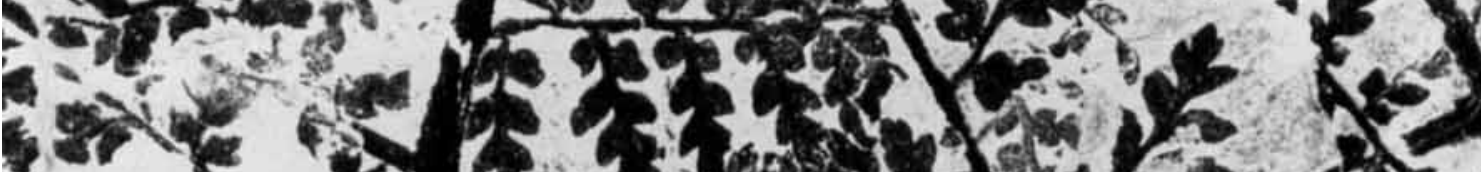
${ }_{4}$,

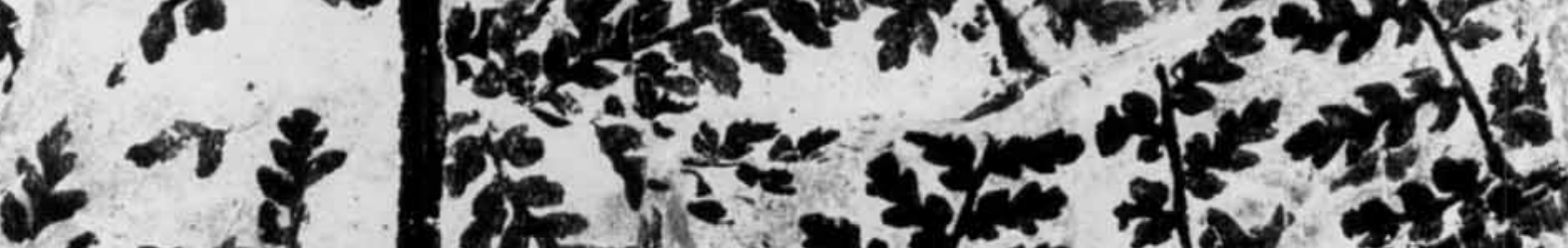

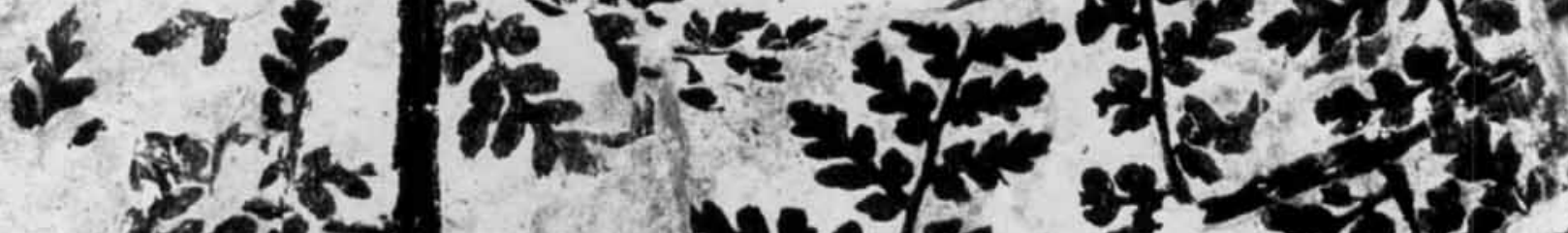

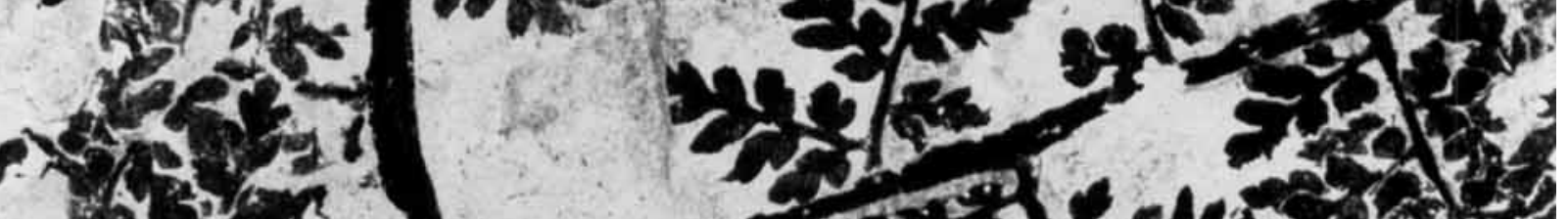

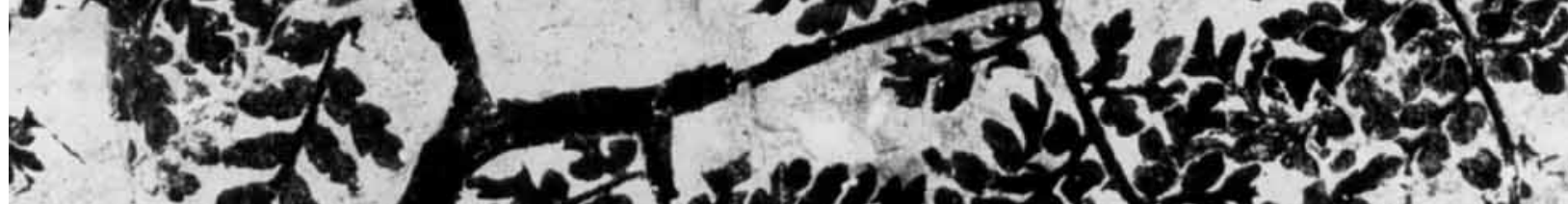

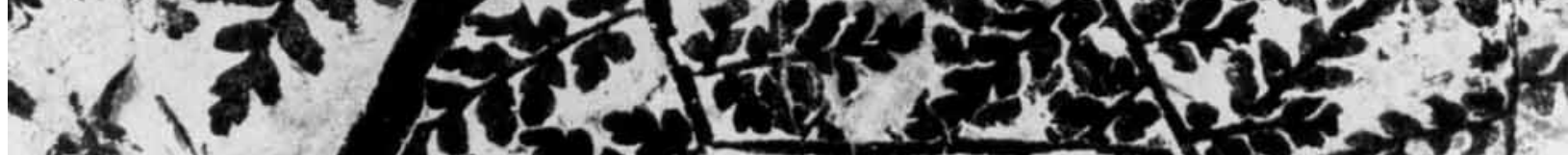
A. 5 :

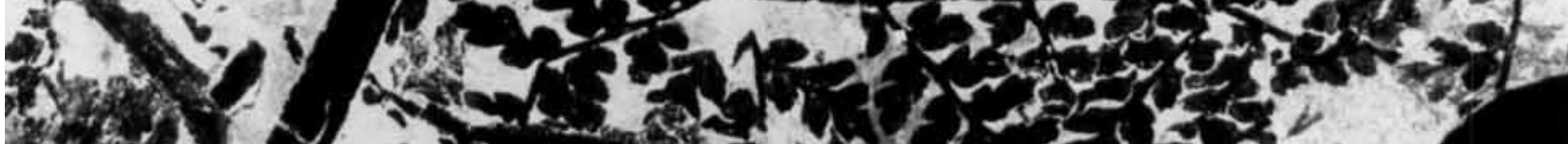

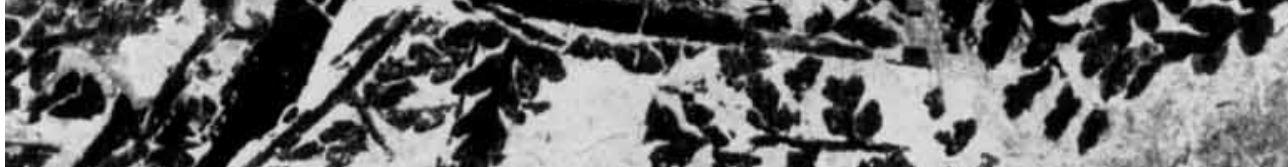

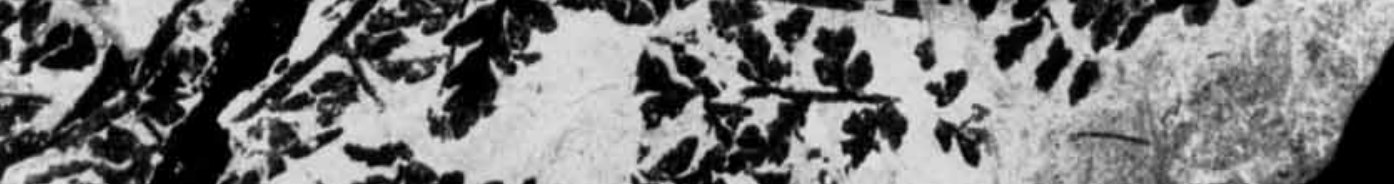
(5.) 

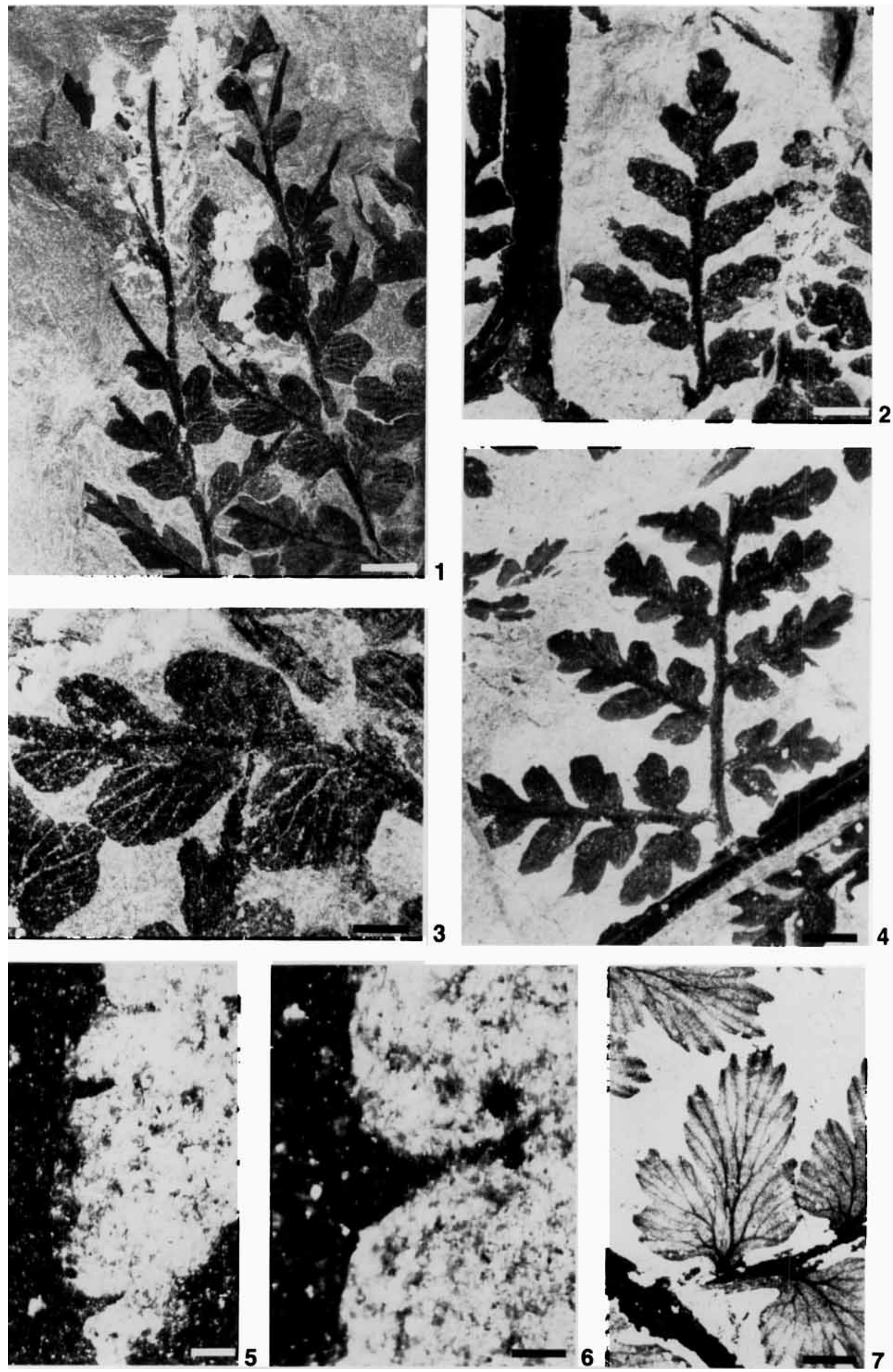
extensions, and dorsal and circum-poral thickenings, but the latter often rather weak; stomatal pores may be partially closed by overarching papillae extending from the subsidiary cells.

\section{Description}

Macromorphology:

The fully differentiated frond of Karinopteris beneckei (Pl. 1) is bipartite, and may well reach up to $45 \mathrm{~cm}$ long. The stipe is at least $10 \mathrm{~cm}$ long, up to $0.8 \mathrm{~cm}$ wide (in compression), and its surface characterized by a few distinct longitudinal striae; transverse sclerotic bars, present in the cortex, are usually recognizable, but often faint. The blade is bi- to tripinnate and rather lax in appearance. The two rachides are basally up to $0.6 \mathrm{~cm}$ wide, slightly sinuous, and longitudinally striated. Stipe and rachides bear projections (i.e., emergences), up to $0.45 \mathrm{~mm}$ long and basally approximately $0.1 \mathrm{~mm}$ wide (Pl. 2: 5, 6). Pinna axes of the penultimate order are alternately positioned, up to $12 \mathrm{~cm}$ long and basally $0.1-0.4 \mathrm{~cm}$ wide on the exterior and up to $9 \mathrm{~cm}$ long and $0.1-0.3 \mathrm{~cm}$ wide on the interior side of the frond, and smooth or with one or two longitudinal striae; they depart from the rachis at angles between $70^{\circ}$ and $90^{\circ}$. Pinna axes of the penultimate order terminate in undifferentiated, usually lobed pinnules, up to $1 \mathrm{~cm}$ long, or climber hooks. There is a distinct difference with regard to morphology between pinnae of the ultimate order in the proximal and uppermost portion of the blade. Fully differentiated pinnae of the ultimate order (cf. PI. 2: 4) only occur in the proximal portion of the blade where they are triangular in general outline, alternately positioned at angles between $55^{\circ}$ and $90^{\circ}, 1.5-4 \mathrm{~cm}$ long, and possess up to nine individual pinnules; the axes are smooth and approximately $0.1-0.15 \mathrm{~cm}$ wide. Towards the tip, pinnae of the penultimate order display a gradual decrease in differentiation of pinnae of the ultimate order, i.e., pinnae with individual pinnules gradually transition into compound and lobed pinnules (Pl. 1: 1; Pl. 2: 2). In fully differentiated pinnae of the ultimate order, the individual pinnules are variable in size and shape (cf. Fig. 1), between 0.3 and $2.0 \mathrm{~cm}$ long, up to $0.6 \mathrm{~cm}$ wide, and alternately arranged. They are usually loosely positioned, oblong (tongue-shaped) in general outline, broadly attached, basiscopically decurrent and often acroscopically constricted, entire-margined to profoundly lobed, and with rounded or somewhat tapered apices. The basally positioned pinnules in fully differentiated pinnae are attached by a pedicel (e.g., Pl. 4: 1) and may possess a weakly-developed basal lobe. Pinnules on the basiscopic side of a pinna are often larger than those on the acroscopic side. The individual pinnules are interconnected by narrow laminar rims on each side along the axis. Pinna axes of the ultimate order teminate in a (slightly) lobed pinnule, which represents a merger of the terminal and the pair of subterminal pinnules, or in climber hooks. The pinnule veins are strong and rather loosely spaced (e.g., Pl. 2: 3); however, in compressions, the venation is often difficult to recognize. One or two lateral veins enter each pinnule lobe at acute angles, and divide one to four times in their course to the margin. The uppermost part of the blade lacks true pinnae of the ultimate order with individual pinnules. Instead of the latter, axes of the penultimate order bear large, compound, and lobed pinnules, which are similar in appearance to the pinnules that occur in the distal portions of fully differentiated pinnae of the penultimate order (see above). The compound pinnules are up to $2.5 \mathrm{~cm}$ long, the lamina basally up to $1 \mathrm{~cm}$ wide. They are constricted at the base and attached by a broad pedicel, up to $0.15 \mathrm{~cm}$ wide. The venation is (partially) well-recognizable. The midvein (i.e.,

Plate 2. Karinopteris beneckei (figs 1-6) and Mariopteris hirsuta (fig. 7) from Lower Silesia (Poland). 1. Pinnae terminating in climber hooks. Frischaufgrube near Eckersdorf, Lower Silesia, Hangendzug, Schatzlarer Schichten (Westphalian A); coll. Beinert, MB.Pb.2002/1020; polarized light; scale bar $=0.5 \mathrm{~cm}$. 2. Detail from Pl. I, fig. 1; pinna of the penultimate order with compound pinnules; slightly polarized light; scale bar $=0.5 \mathrm{~cm}$. 3. Detail from Pl. 2, fig. 1; pinna from the distal portion of the blade, showing the pinnule venation and basal portions of climber hooks; slightly polarized light; scale bar $=0.2 \mathrm{~cm} .4$. Detail from Pl. I; interior side of the frond, pinna from the proximal portion of the frond with pinnae of the ultimate order; slightly polarized light; scale bar $=1.0 \mathrm{~cm}$. 5, 6. Emergences on the rachis (fig. 5) and stipe (fig. 6); specimen originally figured by Huth (1912a: fig. 36). Sophiengrube near Charlottenbrunn, Lower Silesia, Hangendzug, Schatzlarer Schichten (Westphalien A); MB.Pb.1983/109; immersed, polarized light; scale bar $=0.4 \mathrm{~mm}$ (fig. 5), scale bar $=0.2 \mathrm{~mm}$ (fig. 6). 7. Mariopteris hirsuta; specimen originally figured as M. Beneckei by Huth (1912a: fig. 37); basal pinnule showing the venation and trichomes; note that the lobe-tips appear to be stronger cutinized; Lower Silesia, Hangendzug, Schatzlarer Schichten (Westphalian A); MB.Pb.1980/503; immersed, polarized light; scale bar $=0.25 \mathrm{~cm}$. 


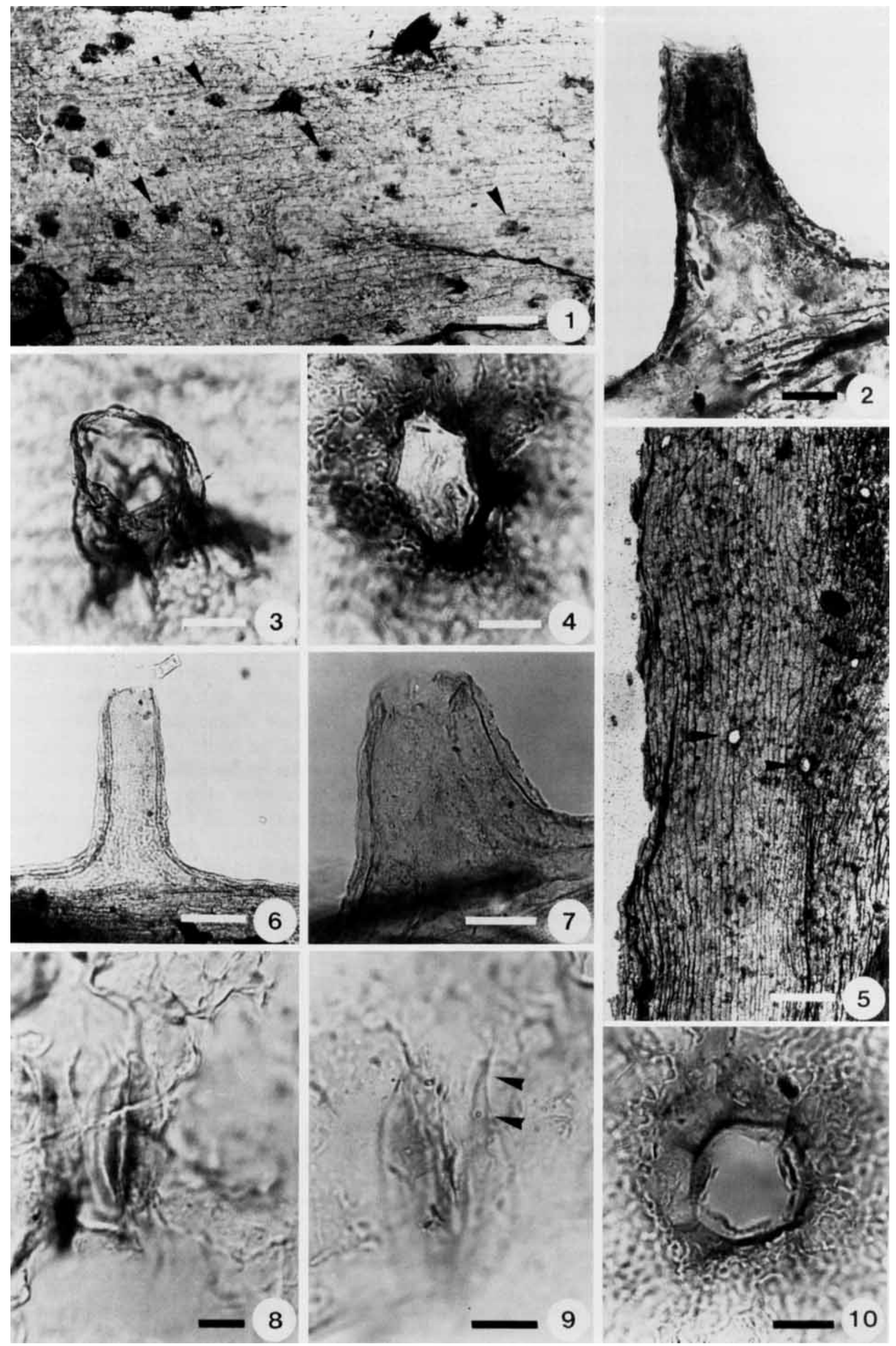


the axis in fully differentiated pinnae of the ultimate order) is prominent, often somewhat flexuous, and extends up to two-thirds of the pinnule length. It gives off lateral veins at acute angles, which are often barely discernible in compressions. The lateral veins are thinner than the midvein and one to four times divided in their course to the margin. Pinnae of the penultimate and ultimate order in the distal portion of the blade sometimes develop climber hooks in the form of apical prolongations ( $\mathrm{Pl} .2$ : 1), which may become more than $2.5 \mathrm{~cm}$ long. The material at hand does not display climber hooks in the proximal portion of the blade.

\section{Epidermal anatomy:}

Cuticles were obtained from the stipe, rachis, pinna axes of the penultimate and ultimate order, and pinnules. The epidermis of the stipe and rachides displays a rather regular cell pattern, consisting of elongate, penta- to heptagonal cells, up to $160 \mu \mathrm{m}$ long and $60 \mu \mathrm{m}$ wide (Pl. 3: 1), which are oriented longitudinally. Differences in the epidermal anatomy between the adaxial and abaxial side of the stipe and rachides are not recognizable. Stomata and the remains of two types of outgrowths are present in the epidermis. The tiny stomata are recognizable only through the dorsal thickenings of the guard cells and heavily cutinized subsidiary cells (Pl.3: 1 [arrows]). Stipe and rachides bear numerous large emergences, of which only the multiseriate basal portions (i.e., the shafts) are preserved ( $\mathrm{Pl} .3: 2$, $6,7)$. These shafts are up to $450 \mu \mathrm{m}$ long and basally between 100 and $150 \mu \mathrm{m}$ wide. They are hollow, suggesting that, at one time, there might also have been subepidermal tissues present. In addition, small round or oval trichome bases occur in the epidermis, which are up to $40 \mu \mathrm{m}$ in diameter (Pl. 3: 3, 4).

The epidermis of the upper surface of pinna axes of the penultimate and, if differentiated, the ultimate order (i.e., the portion between the points of insertion of the pinnules) is rather uniform, consisting of elongate cells, up to $250 \mu \mathrm{m}$ long and $50 \mu \mathrm{m}$ wide. Integrated in the epidermis are circular to oval trichome bases, $25-50 \mu \mathrm{m}$ in diameter, which either do not show any special cutinizations or may be slightly cutinized. The epidermal cell pattern of the lower surface of pinna axes of the penultimate and, if differentiated, the ultimate order consists of elongate, usually acutely ending, penta- to heptagonal cells, up to $550 \mu \mathrm{m}$ long and between 15 and $50 \mu \mathrm{m}$ wide (Pl. 3: 5). Present in the epidermis are shafts of large emergences, identical to those occurring on stipe and rachides. In addition, trichome bases similar to those of the upper pinna axis surface, but often more heavily cutinized, are a regular component of the epidermis. Each trichome base is surrounded by up to seven normal epidermal cells (Pl. 3: 5, 10). Small trichome bases may also be present, each surrounded by up to six epidermal cells, which are strongly cutinized around the opening. Furthermore, larger, oval, often heavily cutinized openings are found, which most probably also represent trichome bases. Minute stomatal apparati occur in the epidermis of penultimate order pinna axes. They consist of a pair of slightly sunken guard cells and an undeterminable number of subsidiary cells, which apparently do not differ from normal epidermal cells (Pl. 3: 8, 9). The guard cells possess weak dorsal and circum-poral thickenings and tapering polar extensions, 3-5 $\mu \mathrm{m}$ long (Pl. 3: 9 [arrows]). The guard cells are $20-25 \mu \mathrm{m}$ long (without the polar extensions) and 5-7 $\mu \mathrm{m}$ wide. Stomata seem to be absent in pinna axes of the ultimate order.

Pinnules are hypostomatic with the cuticle on the upper (adaxial) surface well preserved (Pl. 4: $1,2)$. Above the proximal part of the midvein, the epidermal cell pattern is similar to that of the upper surface of pinna axes of the ultimate

Plate 3. Epidermal features of Karinopteris beneckei from Lower Silesia (Poland): Stipe, rachides, and pinna axes. 1. Cuticle from the stipe, displaying the cell pattern, a few emergences, and stomata [arrows]; slide no. MB.Pb 2002/1009; scale bar = $150 \mu \mathrm{m}$. 2. Shaft of an emergence from the rachis; slide no. MB.Pb 2002/1012; scale bar $=45 \mu \mathrm{m}$. 3, 4. Trichome bases from the stipe; slide no. MB.Pb 2002/1011; scale bar = $15 \mu \mathrm{m}$ (fig. 3), slide no. MB.pb 2002/1013; scale bar = $15 \mu \mathrm{m}$ (fig. 4). 5 . Epidermal anatomy of the abaxial surface of a pinna axis of the penultimate order with trichome bases [arrows]; slide no. Epid.Pr. K23/3; scale bar $=300 \mu \mathrm{m}$. 6, 7. Shafts of emergences from a pinna axis of the penultimate order; slide no. MB.Pb 2002/995; scale bar $=100 \mu \mathrm{m}$ (fig. 6), slide no. Epid.Pr. K 23/6; scale bar $=40 \mu \mathrm{m}$ (fig. 7). 8, 9. Pairs of stomatal guard cells from a pinna axis of the penultimate order; view from the outside, dorsal and circum-poral thickenings recognizable in fig. 8; view from the inside, tapering polar extensions visible in fig. 9 [arrows]; slide no. MB.Pb 2002/1008; scale bar $=6 \mu \mathrm{m}$ (figs 8-9). 10. Trichome base from the abaxial side of a pinna axis of the penultimate order; slide no. Epid.Pr. K 23/6; scale bar $=14 \mu \mathrm{m}$. 


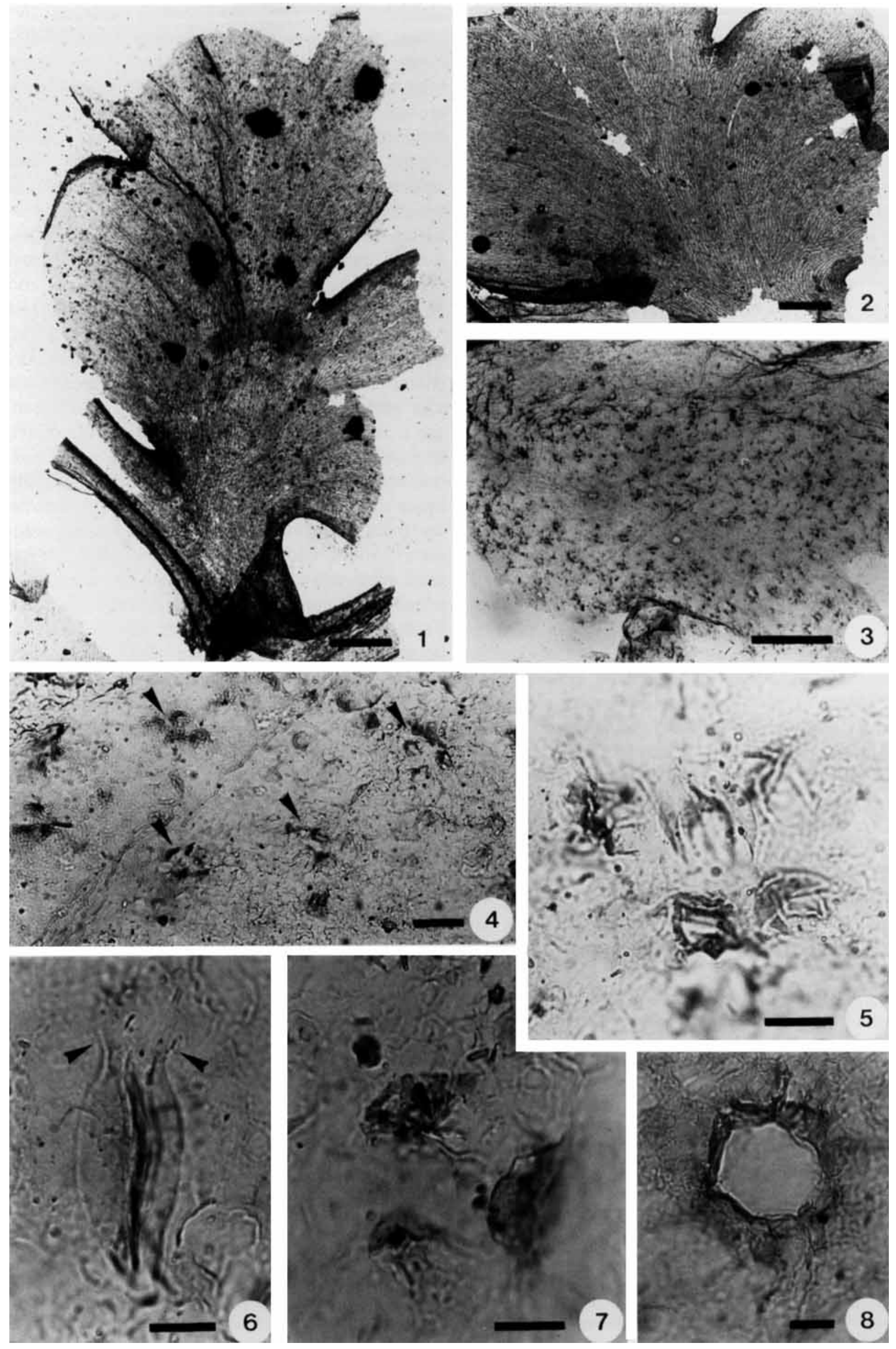


order. The other cells of the adaxial pinnule surface display a diverging pattern from the proximal midvein region. The lamina shows weak differentiation of the epidermis into costal and intercostal fields (Pl. 4: 2). Cells of the costal areas are elongate, up to $300 \mu \mathrm{m}$ long and 25-45 $\mu \mathrm{m}$ wide, and always oriented in longitudinal direction. Cells of the intercostal fields are similar in shape to the former, but usually wider and less regularly arranged. Individual cells are penta- to heptagonal, 60 to $300 \mu \mathrm{m}$ long and between 50 and $75 \mu \mathrm{m}$ wide; near the pinnule margin they may even be longer than $400 \mu \mathrm{m}$. Around the pinnule base, epidermal cells may be more isodiametric. Trichome bases without any special cutinization, between 20 and $45 \mu \mathrm{m}$ in diameter, occur in the upper surface. Cuticles of the lower (abaxial) pinnule surface are thin and transparent, and usually without any identifiable details of the epidermal cell pattern. However, the distribution of hair bases and stomata (Pl. 4: 3 ) indicates that costal and intercostal fields were differentiated. Trichome bases are abundant in the costal fields (Pl. 4: 3); they are circular to slightly oval, between 30 and $50 \mu \mathrm{m}$ in diameter, and not heavily cutinized (Pl. 4: 8). Stomatal apparati are confined to the intercostals fields, poorly preserved, sometimes even difficult to recognize as such. In some specimens, the stomata appear to be arranged in rows. The stomatal apparatus (Pl. 4: 4 [arrows], 5-7) consists of a pair of small guard cells with dorsal and circum-poral thickenings and up to $4 \mu \mathrm{m}$ long tapering polar extensions (Pl. 4: 6 [arrows]), and usually 3-5 subsidiary cells. The guard cells are up to $25 \mu \mathrm{m}$ long (without the polar extensions) and between 5 and $8 \mu \mathrm{m}$ wide. In some specimens, up to $9 \mu \mathrm{m}$ high papillae, extending from the subsidiary cells, partly overarch the guard cells ( $\mathrm{Pl} .4$ : 5, 7), whereas in other specimens, the subsidiary cells lack papillae. In compound pinnules, shafts of large emergences are often present abaxially in the midvein region.

\section{Discussion}

\section{Comparisons:}

Huth (1912a) points out that Karinopteris beneckei is highly variable morphologically; he figures seven specimens (1912a: figs 34-41) in order to demonstrate the intraspecific variability, and especially refers to figure 37 , which shows a specimen that differs considerably from the other material figured. However, Danzé-Corsin (1953) questions the range of variability of $K$. beneckei indicated by Huth, and states that the specimens figured represent several species. Remy \& Remy (1959: 144/145) regard the specimen shown in fig. 37 (refigured here in Pl. 2: 7) as a typical representative of Mariopteris hirsuta. We agree, and submit that not only Huth's figure 37 , but also his figure 40 actually represents $M$. hirsuta. Karinopteris beneckei closely resembles Karinopteris acuta with respect to macromorphology (e.g., Danzé-Corsin 1953). Nevertheless, there are a few features that permit distinction between the two taxa: (1) K. acuta is characterized by tapering pinnule lobes, which have never been observed in $K$. beneckei. (2) The frond of $K$. beneckei is loose in overall appearance, whereas fronds of $K$. acuta usually appear more compact. (3) The pinnule lamina in $K$. beneckei (cf. Pl. 2: 2-4) is reduced in comparison to that of $K$. acuta (according to Danzé-Corsin (1953), the lamina in $K$. beneckei appears "atrophied"). (4) Transverse sclerotic plates in the cortex are prominent in $K$. acuta, but rather weakly developed or even absent in K. beneckei. (5) Karinopteris beneckei produces numerous large emergences on stipe, rachides, and pinna axes, which are well-recognizable in cuticle preparations (Pl. 3: 2, 6, 7), but also visible in compressions (Pl. 2: 5, 6); these structures have been reported only once in K. acuta (i.e., Barthel 1962: 19 and fig. 70a). Nevertheless, the differences presented here are not sufficient to distinguish $K$. beneckei from $K$. acuta with confidence in every case.

Plate 4. Epidermal features of Karinopteris beneckei from Lower Silesia (Poland): Adaxial and abaxial pinnule surfaces. 1. Almost complete adaxial cuticle of a pinnule positioned basally in an ultimate order pinna, with part of the pinna axis still attached; slide no. Epid.Pr. K 23/3; scale bar $=1.0 \mathrm{~mm}$. 2. Epidermal anatomy of the adaxial side of a pinnule; slide no. Epid.Pr. K 23/3; scale bar $=0.75 \mathrm{~mm}$. 3. Cuticle from the abaxial side of a pinnule, showing the differentiation into costal and intercostals fields; slide no. Epid.Pr. K 23/1; scale bar $=380 \mu \mathrm{m}$. 4. Portion of an intercostal field from the abaxial pinnule surface with several stomatal apparati [arrows]; slide no. Epid.Pr. K 23/1; scale bar $=30 \mu \mathrm{m}$. 5. Stomatal apparatus with the guard cells and four papillae extending from the subsidiary cells discernible; slide no. MB.Pb 2002/998; scale bar $=9 \mu \mathrm{m}$. 6 . Pair of guard cells (view from the inside) with tapering polar extensions [arrows] visible; slide no. MB.Pb 2002/998; scale bar $=6 \mu \mathrm{m}$. 7. Stomatal apparatus with three papillae extending from subsidiary cells; slide no. MB.Pb 2002/998; scale bar $=$ $9 \mu \mathrm{m}$. 8. Trichome base from a costal field of the abaxial pinnule surface; slide no. MB.Pb 2002/1008; scale bar =1 $12 \mu \mathrm{m}$. 
Gothan (1935) pointed out that small specimens of $K$. beneckei are almost impossible to discriminate from varieties with rounded pinnule lobes of $K$. acuta. Unfortunately, no description of the epidermal anatomy of $K$. acuta has been provided to date, which could be used to hypothesize the relationship that existed between $K$. beneckei and $K$. acuta based on biological criteria.

The epidermal anatomy of Karinopteris beneckei generally corresponds well with that of a number of other mariopterids. In particular, the epidermal cell pattern of pinna axes of the penultimate and ultimate order, consisting of elongate, usually acutely ending cells (Pl. 3: 5), is widespread in this group of plants, having previously been reported from Karinopteris sp. (DiMichele et al. 1984), Mariopteris muricata (Gothan 1915, Barthel 1962), M. nervosa and M. latifolia (Barthel, 1962), M. occidentalis (Krings et al., 2001b), and Pseudomariopteris busquetii and $P$. cordato-ovata (Krings \& Kerp, 2000), among others. Moreover, the clear differentiation into costal and intercostal fields of the abaxial pinnule epidermis (Pl. 4: 3), but rather weak subdivision into costal and intercostal fields of the adaxial surface ( $\mathrm{Pl} .4: 1,2)$, is typical among these plants (Krings et al. 2001b). Tiny stomata, partly covered by overarching papillae (Pl. 4: 5, 7), and large emergences (Pl. 3: 2, 6, 7) are further features of $K$. beneckei, which also have been noted from other taxa. Their occurrence in other mariopterids and significance with regard to paleoecology are addressed elsewhere in this paper. The consistent occurrence of certain epidermal features and patterns in mariopterid taxa from various geographical regions and geological ages corresponds with the overall consistency of the mariopterid habit (see introduction), and thus supports the hypothesis that Late Carboniferous-Early Permian mariopterids represent a natural group within the seed ferns. On the other hand, the consistent presence of some features (e.g., trichome types and stomatal structure) in different species may also suggest that these forms colonized comparable habitats and/ or were exposed to similar environmental parameters, and thus display similar complements of adaptations.

Paleobiology and paleoecology:

Numerous mariopterid pteridosperms developed hook-like prolongations of pinna axes of the penultimate and/or ultimate order, in some taxa up to 3 or $4 \mathrm{~cm}$ long (e.g., in Karinopteris sp. from the Indiana paper shale, cf. DiMichele et al. 1984, Kerp \& Barthel 1993), which were effective as climbing aids. Scrambling/climbing with multiple hooks is particularly suitable in areas of dense vegetation where the hooks produce frictional resistance by catching and ratcheting between the support plants' branching systems and foliage, and thus form a loose but effective interaction (Menninger 1970, Kerp et al. 2000). There exists considerable interspecific variation among mariopterids with regard to size and morphology of the climber hooks, ranging from simple (usually up to $1.5 \mathrm{~cm}$ long) prolongations with recurved tips to rather complex forms with secondary hooks on the abaxial side (e.g., DiMichele et al. 1984, Kerp \& Krings 1998). Krings et al. (2001b) consider that the different forms of climber hooks may represent adaptations of individual taxa to certain morphological features of their most frequently utilized support media. Karinopteris beneckei also developed climber hooks (Pl. 2: 1). Unfortunately, no cuticles of these structures could be obtained, and thus details of their morphology remain unrevealed. It is interesting to note, however, that, in $K$. beneckei from Lower Silesia, the occurrence of climber hooks appears to be confined in the distal portion of the blade, whereas, in several other mariopterids, pinnae of the ultimate order from nearly every part of the blade may produce hooks (e.g., Boersma 1972: Pl. 2, fig. 57, Krings et al. 2001a: figs 1,6). As to whether these differences are genetically determined, and consistent interspecific variation exists relative to the spatial distribution of climber hooks on the frond, or the arrangement of climber hooks is dependent on environmental parameters, remains equivocal to date. Nevertheless, it seems more likely that the spatial distribution of climber hooks coincides with particular structural features of the vegetation in which the plants lived. For example, in a compact type of vegetation, in which the individual host plants are closely spaced and their aerial parts largely intertwine, a relatively small number of climber hooks positioned distally in the frond may suffice in order to effectively stabilize a small or medium-sized vine/liana. However, in a more open type of vegetation with gaps between the individual host plants, a larger number of climber hooks that are regularly distributed is requisite to securely anchor the scrambler/climber. Pseudomariopteris cordato-ovata, a mariopterid from the Stephanian, adds further support to the assumption that environmental factors affected the development of 
climber hooks. The hooks in this taxon are up to $1.5 \mathrm{~cm}$ long and terminate in two recurved hooklets. Sometimes, however, pinnae of the ultimate order terminate in two well-developed hooklets, but prolongation of the axis is missing (cf. Krings \& Kerp 2000: Pl. XI, fig. 1). This feature suggests that, at some point, development of the climber hook requires an external stimulus, and, without this stimulus, growth is discontinued. On the other hand, the fossil record of mariopterids indicates that climber hooks were not the only structures effective as climbing aids, but that stems and shoot-borne roots may also have had capacity for attachment and providing mechanical stability, respectively (Krings et al. 2001a, Krings pers. obser.). Thus, it is also possible to envisage that, in $K$. beneckei, alternative modes of attachment have provided sufficient support and the number of climber hooks is reduced. However, the specimens of $K$. beneckei we are aware of do not provide evidence for the presence of alternative strategies for attachment.

The stomatal apparati of pteridosperms can be highly significant as proxy records with regard to paleoenvironmental conditions. In Karinopteris beneckei, however, the stomatal apparati display only a few morphological features that can be interpreted as adaptations to special physiological requirements of the plant. The stomata are characterized by circum-poral and dorsal (Pl. 3, fig. 8) thickenings of the guard cells. These features do not represent special adaptations, but are typical for many late Paleozoic pteridosperms (Krings \& Kerp 1999) and other fossil and extant gymnosperms (Porsch 1905, NappZinn 1966). Stomata with dorsal and circum-poral thickenings of the guard cells have previously been documented for pteridosperms from various form-taxa, including Alethopteris sullivantii, Neuropteris scheuchzeri (Reihman \& Schabilion, 1985), Alethopteris subdavreuxi (Barthel, 1962), Blanzyopteris praedentata (Krings \& Kerp, 1999), Helenopteris paleaui (Krings \& Kerp, 2000), Neuropteris cordata (Krings, 2000), and Odontopteris minor f. zeilleri (Kerp \& Krings in press). However, in comparison to most of these species, the stomata of $K$. beneckei are conspicuously small. Similarly small stomata have been reported for several other mariopterid taxa, including Mariopteris nervosa, M. latifolia (Barthel, 1962), M. occidentalis (Krings et al., 2001b), Pseudomariopteris busquetii, and P. cordato-ovata (Krings \& Kerp, 2000). Perhaps, the minuteness of the stomata is linked to the scrambling/climbing growth habit of these plants. This habit represents a phy- siological challenge because water and nutrients must be transported through a long and slender stem with narrow xylem area to supply a large area of photosynthetically active leaf tissue (Gessner, 1956). Thus, minute stomata may be interpreted as a protection against excessive water loss. In addition, in some $K$. benecke $i$ specimens, the pores of the pinnule stomata are partially closed by papillae extending from the subsidiary cells ( $\mathrm{Pl} .4: 5,7)$. The reduction of the exposure of the stomatal pore by overarching papillae may also be interpreted as an adaptation to avoid excessive transpiration (Kerp \& Barthel, 1993).

The most conspicuous epidermal features of Karinopteris beneckei are large emergences (Pl. 2: 5, 6, Pl. 3: 2, 6, 7), which occur on the stipe, rachides, abaxially on pinna axes of the penultimate order, abaxially on pinna axes of the ultimate order, and in the midvein region of compound pinnules. Unfortunately, the incomplete preservation of the structures (i.e., the apical part is always missing) makes it difficult to comment on their nature. However, comparable structures in more complete preservation have been documented from other mariopterids (e.g., Mariopteris muricata [Kidston, 1925: Pl. CXLV, figs 8-10], $M$. cf. muricata [Walton, 1923: Pl. IX, fig. 5], M. nervosa [Kidston, 1925: Pl. CLIII, fig. 6], M. (al. Karinopteris) acuta [Barthel, 1962: fig. 70a]). They represent capitate glandular emergences, which consist of a cylindrical, multiseriate and multicellular shaft, upon which a spherical secretory cell is positioned. Based on correspondences in morphology and distribution between the shafts of these structures and the cylindrical fragments observed from $K$. beneckei, we hypothesize that the latter also belong to capitate glandular emergences. It is fruitless to speculate in detail about their paleoecological functions in $K$. beneckei. However, provided that the emergences are of glandular nature, they may have been effective in herbivory abatement. This interpretation is supported by accounts in the literature for glandular trichomes of Late Carboniferous pteridosperms that, based on comparisons with extant plants, have been interpreted as effective in discouraging plant-feeding arthropods (Cleal \& Shute 1991, Krings et al. 2002). Moreover, herbivorous arthropods became increasingly abundant during the Late Carboniferous (Labandeira \& Sepkoski 1993), and thus the capacity to face this ecological challenge no doubt represented an advantage in the coal swamp forest. 


\section{Acknowledgements}

This research was supported by the Deutsche Forschungsgemeinschaft (Habilitation Scholarship KR 2125/1-1 to M. K.). The authors would like to thank Manfred Barthel (Berlin) for ceding to us several of his cuticle slides of Karinopteris beneckei (slide numbers Epid.Pr. K23/1-7), Sharon D. Klavins (Lawrence, KS) and Hans Kerp (Münster) for valuable discussion and critical review of the manuscript. We are grateful to Carola Radke (Berlin) for photographs and Jörg-Peter Mendau (Berlin) for the drawings.

\section{References}

Barthel, M. 1962. Epidermisuntersuchungen an einigen inkohlten Pteridospermenblättern des Oberkarbons und Perms. - Geologie 11, Beiheft 33: 1-140.

Boersma, M. 1972. The heterogeneity of the form genus Mariopteris Zeiller - a comparative morphological study with special reference to the frond composition of WestEuropean species. Ph.D. Thesis, University Utrecht, 172 pp + atlas, Drukkerij Elinkwijk, Utrecht.

- 1973. On the genus Mariopteris. In Geologisches Landesamt Nordrhein-Westfalen, Krefeld (ed.). Compte Rendu Septième Congrès International de Stratigraphie et de Géologie du Carbonifère, Krefeld, August 23-28, 1971, Band II. pp. 145-157, Krefeld.

Cleal, C. J. \& Shute, C. H. 1991. The Carboniferous pteridosperm frond Neuropteris heterophylla (Brongniart) Sternberg. - Bulletin of the British Museum of Natural History (Geology) 46: 153-174.

Danzé-Corsin, P. 1953. Les Mariopteris du Nord de la France. - Service Géologique H.B.N.P.C., Études géologiques pour l'atlas de la topographie souterraine. 1. Flore fossile. Contribution à l'étude des Marioptéridées. $269 \mathrm{pp}+$ atlas, Douriez-Bataille, Lille.

Dijkstra, S. J. \& van Amerom, H. W. J. 1983. Fossilium Catalogus. II. Plantae. Filicales, Pteridospermae, Cycadales. $2^{\text {nd }}$ supplement. Pars 90: 293-460, Kugler Publications, Amsterdam.

DiMichele, W. A., Rischbieter, M. O., Eggert, D. L. \& Gastaldo, R. G. 1984. Stem and leaf cuticle of Karinopteris: source of cuticles from the Indiana "Paper" Coal. American Journal of Botany 71: 626-637.

Gessner, F. 1956. Der Wasserhaushalt der Epiphyten und Lianen. In Ruhland, W. (ed.). Handbuch der Pflanzenphysiologie, 3: 915-950, Springer Verlag, Berlin.

Gothan, W. 1915. Über die Methoden und neue Erfolge bei der Untersuchung kohlig erhaltener Pflanzenreste. - Sitzungsberichte der Gesellschaft Naturforschender Freunde Berlin 12: 43-48.

- 1935. Die Steinkohlenflora der westlichen paralischen Steinkohlenreviere Deutschlands. - Abhandlungen der preußischen geologischen Landes-Anstalt, Neue Folge 167: $1-58$.

Huth, W. 1912a. Die fossile Gattung Mariopteris in geologischer und botanischer Beziehung. Ph. D. Thesis, Friedrichs-Universität Berlin. 88 pp. [published also in Potonié, $\mathrm{H}$. (ed.). Abbildungen und Beschreibungen fossiler Pflanzen 8, numbers $141-156$, Königlich Preußische Geologische Landesanstalt, Berlin].

- 1912b. Über die Epidermis von Mariopteris muricata. Paläobotanische Zeitschrift 1: 7-14.

- 1913a. Mariopteris Zeiller. In Gothan. W. (ed.). Die oberschlesische Steinkohlenflora. Teil I. - Abhandlungen der Königlich Preußischen Geologischen Landesanstalt, Neue Folge 75: 84-102.

- 1913b. Zur Kenntnis der Epidermis von Mariopteris muricata. - Zeitschrift der Deutschen Geologischen Gesellschaft, Monatsberichte 65: 143-156.
- 1913c. Beiträge zur Kenntnis der Carbongattung Mariopteris und ihrer Arten. - Zeitschrift der Deutschen Geologischen Gesellschaft, Monatsberichte 65: 372-387.

Jongmans, W. J. 1953. Palaeontological notes on the coalfields of the province of Gelderland in the Eastern Netherlands. - Mededelingen van de Geologische Stichting, Serie C-III-1 2: 5-25.

- 1956. Notes paléobotaniques sur les Bassins houillers de l'Anatolie. - Mededelingen van de Geologische Stichting, Nieuwe Serie 9: 55-89.

Jongmans, W. J. \& Dijkstra, S. J. 1960. Fossilium Catalogus. II. Plantae. Filicales, Pteridospermae, Cycadales. Pars 44. pp. 1453-1596, W. Junk, 's-Gravenhage.

- 1968. Fossilium Catalogus. II. Plantae. Filicales, Pteridospermae, Cycadales. Pars 68. pp. 3903-3988, W. Junk, 'sGravenhage.

Jongmans, W. J. \& Gothan, W. 1915. Paläobotanisch-stratigraphische Studie im Niederländischen Carbon nebst Vergleichen mit umliegenden Gebieten, mit Anhang: Bemerkungen über einige der in den niederländischen Bohrungen gefundenen Pflanzen. - Königlich Preussische Geologische Landesanstalt, Berlin. Archiv für Lagerstättenforschung 18: $1-186$.

Kerp, H. \& Barthel, M. 1993. Problems of cuticular analysis of pteridosperms. - Review of Palaeobotany and Palynology 78: $1-18$.

Kerp, H. \& Krings, M. 1998. Climbing and scrambling growth habits: common life strategies among Late Carboniferous seed ferns. - Comptes Rendus de l'Académie des Sciences de Paris, Série IIa 326: 583-588.

- 1999. Light microscopy of fossil cuticles. In Jones, T. P. \& Rowe, N. P. (eds). Fossil Plants and Spores: Modern Techniques: $52-56$, Special publication of the Geological Society, London.

- (In press). Kutikularanalytische Befunde zur Abgrenzung der Odontopteris minor f. zeilleri Potonié von Odontopteris reichiana Gutbier. - Courier Forschungsinstitut Senckenberg.

Kerp, H., Krings, M. \& Taylor, T. N. 2000. Morphological and biomechanical diversity among late Palaeozoic seed ferns - scrambling and climbing growth habits. In Spatz, H. C. \& Speck, T. (eds). Plant Biomechanics 2000. Proceedings of the $3^{\text {rd }}$ Plant Biomechanics Conference Freiburg-Badenweiler August $27^{\text {th }}$ to September $2^{\text {nd }} 2000$ : 117-122, Thieme Verlag, Stuttgart.

Kidston, R. 1925. Fossil plants of the Carboniferous rocks of Great Britain. - Memoirs of the Geological Survey of Great Britain, Palaeontology II (6): 523-670.

Krings, M. 2000. Zur Morphologie der Spaltöffnungsapparate von Neuropteris cordata (Pteridospermopsida, ?Medullosales) aus dem französischen Oberkarbon. - Botanische Jahrbücher für Systematik, Pflanzengeschichte und Pflanzengeographie 122: 551-566.

Krings, M. \& Kerp, H. 1999. Morphology, growth habit, and ecology of Blanzyopteris praedentata (Gothan) nov. comb., a climbing neuropteroid seed fern from the Stephanian of central France. - International Journal of Plant Sciences 160: 603-619.

- 2000. A contribution to the knowledge of the pteridosperm genera Pseudomariopteris Danzé-Corsin nov. emend. and Helenopteris nov. gen. - Review of Palaeobotany and Palynology 111: 145-195.

Krings, M., Kerp, H., Taylor, E. L. \& Taylor, T. N. 2001a. Reconstruction of Pseudomariopteris busquetii, a vine-like Late Carboniferous - Early Permian pteridosperm. American Journal of Botany 88: 767-776.

Krings, M., Taylor, T. N., Taylor, E. L., Axsmith, B. J. \& Kerp, H. 2001b. Cuticles of Mariopteris occidentalis White nov. emend. from the Middle Pennsylvanian of Oklahoma (USA), and a new type of climber hook for mariopteroid pteridosperms. - Review of Palaeobotany and Palynology 114: 209-222. 
Krings, M., Taylor, T. N. \& Kellogg, D. W. 2002. Touch-sensitive glandular trichomes: a mode of defense against herbivorous arthropods in the Carboniferous. - Evolutionary Ecology Research 4: 779-786.

Labandeira, C. C. \& Sepkoski, J. J. 1993. Insect diversity in the fossil record. - Science 261: 310-315.

Lutz, J. 1938. Die Karbon-Flora des Saargebietes. Abteilung 4: Pteridospermales. Lieferung 1: Mariopteris. - Palaeontographica, Suppl.-Bd. IX (4): 1-34.

Menninger, E. A. 1970. Flowering vines of the world. An encyclopedia of climbing plants. 410 pp., Hearthside Press Inc., New York.

Migier, T. 1972. Charakterystyka florystyczna karbonu produktywnego Górnośląskiego Zagłębia Węglowego [Floral characteristics of the Coal Measures in the Upper Silesian Basin]. - Prace Instytutu Geologicznego 61: 135-182.

- 1973. Charakterystyka florystyczna warstw porêbskich (Namur A) okolic Katowic i Chorzówa [Characteristics of floras of the Poreba Beds (Namurian A) in the vicinity of Katowice and Chorozów]. - Kwartalnik Geologiczny 17: $247-251$.

Napp-Zinn. K. 1966. Anatomie des Blattes. I. Blattanatomie der Gymnospermen. In Zimmermann, W., Ozenda, P. \& Wulff, H. D. (eds). Handbuch der Pflanzenanatomie. Spezieller Teil, Band VIII, Teil 1. 369 pp., Gebr. Borntraeger, Berlin.

Novik, E. O. 1952. Kamennougolnaya flora evropeiskoi chasti SSSR [Carboniferous flora of the European part of the USSR]. 468 pp. + 71 plates, Akademiia Nauk SSSR, Paleontological Institute, Moscow.
Porsch, O. 1905. Der Spaltöffnungsapparat im Lichte der Phylogenie. „Ein Beitrag zur phylogenetischen Pflanzenhistologie“: 196 pp. + 4 plates, Gustav Fischer Verlag, Jena.

Potonié, R. 1913. Über Blatt-Epidermen einiger fossiler Pteridospermen“. - Sitzungsberichte der Gesellschaft Naturforschender Freunde Berlin 10: 453-461.

Reihman, M. A. \& Schabilion, J. T. 1985. Stomatal structure of Alethopteris sulivantii and Neuropteris scheuchzeri, Pennsylvanian pteridosperm foliage. - American Journal of Botany 72: 1392-1396.

Remy, W. \& Remy, R. 1959. Pflanzenfossilien. Ein Führer durch die Flora des limnisch entwickelten Paläozoikums. 285 pp., Akademie Verlag, Berlin.

Steur, H. 1995. Mariopteris und Karinopteris, kletternde Samenfarne aus dem Karbon. - Fossilien 6: 331-338.

Stopa, S. Z. 1957. Rośliny Paprociolistne (Pteridophylla) górnego Namuru i Najniższego Westfalu na górnym śląsku [Les feuilles de Fougères (Pteridophylla) du Namurien supérieur et du Westphalien le plus bas dans le bassin houiller de la Haute Silésie]. 208 pp +37 plates, Drukarnia Narodowa W Krakowie, Warszawa.

Walton, J. 1923. On a new method of investigating fossil plant impressions or incrustations. - Annals of Botany 37: 379-391.

Zalessky, M. D. \& Cirkova, T. H. 1938. The fossil flora of the middle section of the Carboniferous rocks of the Donetz basin. - Transactions of the Central Geology and Prospection Institute 98: 154-169. 